\title{
Fulmer Modeline Dayalı Finansal Başarısızlık İle Finansal Performans İlişkisi: İmalat Sanayi Üzerine Bir Uygulama
}

\author{
İlhan EGE* \\ Emre Esat TOPALOĞLU** \\ Asli YIKILMAZ ERKOL ${ }^{* * *}$
}

\section{$\ddot{O Z Z T T}$}

Çalışmada, finansal başarısızlık ile finansal performans arasındaki ilişkiyi ortaya çıkarmak amaçlanmıştır. Bu bağlamda Borsa Ístanbul 100 Endeksi'ndeki imalat sanayi firmalarının 2011-2015 dönemindeki verileri, panel veri analiz yöntemi ile incelenmiştir. Finansal başarısızlı, Fulmer H-Skoru ile temsil edilirken, finansal performans ise Tobin's $Q$ oranı ile temsil edilmiştir. Ayrica finansal performansı etkilediği düşünülen aktif karlılık oranı, satışların logaritması ve fiyat/kazanç oranı analize kontrol değişkenleri olarak dâhil edilmiştir. Analiz sonucunda, Fulmer H-Skoru ile Tobin's Q oranı arasında pozitif ve anlamlı bir ilişki tespit edilmiştir. Diğer bir deyişle firmaların finansal başarısızlık düzeyleri azaldıkça, finansal performans ve firma değeri artmaktadır. Ayrıca çalışmada, aktif karlılık ve fiyat/kazanç oranları ile Tobin's $Q$ oranı arasında pozitif ve anlamlı bir ilişki tespit edilirken, bir diğer kontrol değişkeni olan firma büyüklüğ̈̈ ile anlamlı bir ilişki tespit edilememiştir.

Anahtar Kelimeler: Fulmer H-Skor, Finansal Başarısızlık, Finansal Performans, Borsa İstanbul, Imalat Sanayi.

JEL Sinıflandırması: G10, G17, L25, L60.

\section{Relationship of Fulmer Model Based Financial Distress And Financial} Performance: An Application on The Manufacturing Industry

\section{ABSTRACT}

In this study, it was aimed to reveal the relationship between financial distress and financial performance. In this context, the data of the manufacturing industry firms in Borsa İstanbul 100 Index for 2011-2015 period were analyzed by panel data analysis. Financial distress was represented by the Fulmer $H$-Score, while financial performance was represented by Tobin's $Q$. In addition, the return on assets, log of sales and pricelearning ratio, which are considered to affect financial performance, are included as control variables. As a result of the analysis, a positive and significant relationship was found between Fulmer H-Score and Tobin's $Q$. In other words, as financial distress levels of firms decrease, financial performance and firm value increase. Furthermore, when a positive and significant relationship was found between the return on assets and pricelearnings ratios and Tobin's $Q$, no significant relationship was found with the size of firm which is another control variable.

Keywords: Fulmer H-Score, Financial Distress, Financial Performance, Borsa Istanbul, Manufacturing Industry.

Jel Classification: G10, G17, L25, L60.

\footnotetext{
* Doç. Dr. İlhan Ege, Mersin Üniversitesi, İktisadi ve İdari Bilimler Fakültesi,

İlhanege2005@hotmail.com

** Arş. Gör. Emre Esat Topaloğlu, Mersin Üniversitesi, İktisadi ve İdari Bilimler Fakültesi, İşletme Bölümü, emresatopal@ hotmail.com

*** Arş. Gör. Aslı Yıkılmaz Erkol, Mersin Üniversitesi, İktisadi ve İdari Bilimler Fakültesi, İşletme

Bölümü, asli_yikilmaz@hotmail.com
} 


\section{GíRiș}

Finansal sınırların küreselleşme ile ortadan kalkması, firmaları belirsizliğe sürüklemiş ve firmaların bu koşullarda piyasadaki varlıklarını devam ettirebilmek için gerekli olan kararları doğru bir şekilde alamamalarına neden olmuştur. Belirsizlik ortamında doğru karar alamayan firmalar, finansal yükümlülüklerini karşılamada zorlanmakta ve temelinde finansal sıkıntı ve iflas maliyetleri olan finansal başarısızlık ile karşılaşmaktadır.

Finansal başarısızlık, firma içi ve dışı faktörlerden etkilenmektedir. Resesyon veya enflasyon dönemlerinde uygulanan sık1 para ve kredi politikası, faiz oranların yüksek olması ve firmaların risklilik düzeylerinin artması gibi faktörler, başarısızlığ etkileyen dış faktörler olarak söylenebilir. Diğer taraftan firma içerisindeki yönetimsel hatalar, verimsiz yatırımlar, paydaşlar arasındaki çıkar çatışmaları neticesinde ortaya çıkan maliyetler, pazarlama yanlışlıkları ve finansman yetersizlikleri de finansal başarısızlığa etki eden iç faktörler olarak söylemek mümkündür. Dolayısıyla finansal başarısızlığın firma içi ve dışı nedenlerden kaynaklandığı ifade edilebilir (Aktaş, vd. 2003: 2).

Firmaların finansal olarak başarısız olmalarına yol açabilecek iç ve dış faktörlerin olumsuz etkileri, önceden alınacak tedbirler ile en aza indirilebilmektedir. Dolayısıyla finansal başarısızlığın olası etkilerinden firmayı ve paydaşlarını koruyabilmek ve gerekli önlemlerin alınabilmesini sağlayabilmek için finansal başarısızlığın öngörülmesi gerekmektedir. Finansal başarısızlığın önceden tahmin edilmesi, bu kriteri dikkate alarak yatırım yapan ya da kredi veren kişi veya kurumların yatırımlarında değer kaybına uğramaması ve alacakların tahsil edilememe riskini en aza indirmektedir (Selimoğlu ve Orhan, 2015: 22). Bu doğrultuda finansal başarısızlığın öngörülebilmesi için çok boyutlu başarısızlık analizlerini içeren istatistiki ve ekonometrik yöntemler kullanılabilmektedir. Literatürde başarısızlığın tespit edilmesinde genellikle çoklu diskriminant analiz yöntemlerinden faydalanıldı̆̆ını söylemek mümkündür. Bu yöntemler, Altman Z-Skor modeli, Springate S-Skor modeli, Fulmer H-Skor modeli, Zmijewski J-Skor modeli ve Canada Skoru modeli olarak ifade edilebilir.

Fulmer vd. (1984) tarafindan geliştirilen H Skor modeli, ortalama aktif büyüklükleri 455 Milyon Dolar olan 30 başarılı ve 30 başarısız olmak üzere toplam 60 Amerikan firması üzerinde test edilmiştir. H Skoru, karlılık, kaynak yapısı, likidite ve borç ödeme yeterliliğini kapsayan farklı ve eşit olmayan ağırlıklara sahip 9 faktörden oluşan bir fonksiyonu ifade etmektedir. Fulmer vd., kurguladıkları modelde hangi faktörlerin diğer bir deyişle finansal oranların ve katsayıların kullanılacağına karar vermişlerdir. Finansal oranlar, belirlenen katsayılar ile çarpılarak ve belirli yerlerde 
toplanıp çıkarılarak H Skoru hesaplanmaktadır. H Skora ilişkin finansal oranlar ve bu doğrultuda oluşturulan fonksiyon aşağıdaki gibi ifade edilmektedir.

Tablo 1. Fulmer Modeli Faktörler ve Fonksiyonu

\begin{tabular}{ll}
\hline Faktörler & Fonksiyon \\
\hline (X1) Dağıtılmamış Kar/T. Varlık & \\
(X2) Satış/T. Varlık & \\
(X3) Vergi Öncesi Kar/Özsermaye & H-Skoru \\
(X4) Nakit/Toplam Borç & $5,52 X 1+0,212$ X2+0,073X3+1,27X4- \\
(X5) Toplam Borç/T. Varlık & $0,12 X 5+2,34 X 6+0,575 X 7+1,083 X 8+$ \\
(X6) Kısa Vadeli Borç/T. Varlık & 0,894 X9-6,075 \\
(X7) Log(Maddi Duran Varlık) & \\
(X8) Çalışma Sermayesi/Toplam Borç & \\
(X9) Log Faiz ve Vergi Öncesi K./Faiz & \\
\hline
\end{tabular}

Yukarıda Tablo 1'deki eşitlik doğrultusunda hesaplanan H-Skoru 0'dan küçük olan firmaların finansal sıkıntı ve iflas maliyetleri ile karşı karşıya olduğu belirtilmiştir. Dolayısıyla bu firmaların finansal olarak başarısız oldukları kabul edilmektedir. Buna karşın H-Skoru 0'dan büyük olan firmaların ise finansal sıkıntı ve iflas maliyetleri ile karşılaşma olasılıklarının düşük düzeyde olduğu da ifade edilebilmektedir.

Literatürde firmaların finansal başarısızlıklarını belirleyebilmek amacıyla kullanılan tahmin modellerine ilişkin çeşitli çalışmalar bulunmaktadır. Bu bağlamda literatürde finansal başarısızlık, genellikle tahmin boyutunda ele alınmıştır. Dolayısıyla uluslararası yazında, finansal başarısızlık ile finansal performans arasındaki ilişkiye yönelik olarak gerçekleştirilen az sayıda çalışma söz konusu iken, ulusal yazında herhangi bir çalışmaya rastlanılmamıştır. Bu çalışmalarda elde edilen bulgulara ilişkin açıklamalar, kronolojik sıralama esas alınarak belirtilmiştir.

Opler ve Titman (1994), finansal başarısızlık ile finansal performans arasındaki ilişkinin incelendiği çalışmada, yüksek kaldıraç oranına sahip firmaların finansal sıkıntı dönemlerinde piyasa paylarında ve özsermaye piyasa değerlerinde rakiplerine göre azalış tespit edilmiştir. Bu bulgu dolaylı maliyetler ile finansal başarısızlık arasındaki pozitif ve anlamlı ilişki ile tutarlık göstermektedir. Ayrıca çalışmada, büyük ölçekli endüstrilerde finansal kaldıracın olumsuz etkilerinin daha yüksek olduğu da ortaya çıkarılmıştır.

Campbell, Hilscher ve Szilagyi (2011), 1991-2008 yılları arasında başarısız hisse senetlerine sahip olan firmaların finansal başarısızlıklarının ve finansal performanslarının tahmin edildiği çalışmada, gelecekteki finansal başarısızlıkların tahmini piyasa ve muhasebe bazlı ölçüm yöntemleri doğrultusunda gerçekleştirilmiştir. Analiz sonucunda, sıkıntılı hisse senetlerinin değişken getirilere sahip olduğu ve yüksek 
risk taşıdıkları tespit edilmiştir. Ayrıca çalışmada yatırımcıların katlandıkları riskler doğrultusunda ek bir kazanç elde edemedikleri ortaya çıkarılmıştır.

Tan (2012) tarafından yapılan çalışmada, 8 Doğu Asya ülkesinden 277 firmanın finansal kriz döneminde finansal başarısızlıkları ile finansal performansları arasındaki ilişki incelenmiştir. Çalışmada finansal performans aktif karlılık oranı ve Tobin's Q ile ölçülürken, finansal başarısızlık ise finansal kaldıraç oranı ile temsil edilmiştir. Analiz sonucunda borçlanma oranının düşük olduğu firmaların performansları, borçlanma oranı yüksek olanlara göre daha iyi olduğu belirlenmiştir. Ayrıca çalışmada, kriz döneminde firmaların finansal performansları ile finansal başarısızlıkları arasında negatif yönlü ilişki tespit edilmiştir. Diğer bir ifadeyle kriz döneminde yüksek borç düzeyine sahip firmaların düşük performans sergiledikleri tespit edilmiştir.

Yusuf, Karim ve Yunus (2014) çalışmalarında, 1990-2010 döneminde Malezya'da faaliyet gösteren yerel bankaların finansal başarısızlıklar ile finansal performansları arasındaki ilişkiyi ortaya çıkarmak amaçlanmıştır. Çalışmada finansal performans özsermaye karlılık oranı ile ölçülürken, finansal başarısızlık ise kredi kayıp karşı1ı̆̆ı/toplam borç oranı ile belirlenmiştir. Analiz sonucunda finansal başarısızlık ile finansal performans arasında istatistiksel olarak anlamlı ve negatif yönlü ilişki tespit edilmiştir.

Shahwan (2015) çalışmasında, gelişmekte olan piyasalardan biri olan Misır Borsasında işlem gören ve finansal nitelikte olmayan 86 firmanın kurumsal yönetim endeks puanı ile finansal performansa ve finansal başarısızlığa olan etkisini ortaya çıkarmak amaçlanmıştır. Çalışmada finansal performans Tobin's Q ile ölçülürken, finansal başarısızlık ise Altman Z-Skoru ile hesaplanmıştır. Analiz sonucunda, firmaların kurumsal yönetim düzeylerinin düşük olduğu, kurumsal yönetim ile finansal performans arasında pozitif bir ilişkinin olmadığı ve finansal başarısızlık ile kurumsal yönetim arasında ise anlamlı olmayan negatif yönlü bir ilişkinin varlığı tespit edilmiştir.

Shaukat ve Affandi (2015), Pakistan Karachi Borsasında 2007-2012 y1lları arasında faaliyet gösteren 15 yakıt ve enerji firmasının analize dâhil edildiği çalışmada, finansal başarısızlığın finansal performansa olan etkisi araştırılmıştır. Çalışmada finansal performans aktif karlılık oranı, geçmiş yıl karı/toplam aktif oranı ve çalışma sermayesi/toplam aktif ile belirlenirken, finansal başarısızlık ise Altman Z-Skor ile belirlenmiştir. Analiz sonucunda finansal başarısızlık ile finansal performans arasında istatistiksel olarak anlamlı ve negatif yönlü bir ilişki tespit edilmiştir. Diğer bir deyişle, Z-Skoru yüksek olan firmalarda finansal başarısızlığın düşük, finansal performansın ise yüksek olduğu ortaya çıkarılmıştır.

Delavar, Kangarluei ve Motavassel (2015), 2004-2012 döneminde Tahran Borsası'nda faaliyet gösteren 71 firmanın incelendiği çalışmada, finansal performans çalışma sermayesi ve finansal başarısızlık arasındaki ilişki analiz edilmiştir. Çalışmada 
finansal performans Tobin's Q ile temsil edilirken, finansal başarısızlık ise Altman ZScore ile temsil edilmiştir. Analiz sonucunda, finansal başarısızlık ile çalışma sermayesi ve finansal performans arasında herhangi bir ilişki tespit edilememiştir.

Bu çalışmada, Borsa İstanbul'da (BIST) faaliyet gösteren firmaların finansal başarısızlıkları ile finansal performansları arasındaki ilişkiyi ortaya çıkarmak amaçlanmıştır. $\mathrm{Bu}$ bağlamda BIST 100 endeksi içerisinde devamlı olarak faaliyet gösteren 19 imalat sanayi firmasının 2011-2015 dönemindeki verileri, panel veri yöntemi ile analiz edilmiştir. Çalışmada finansal başarısızlık Fulmer H-Skoru kullanılarak tespit edilirken, finansal performans ise Tobin's Q ile belirlenmiştir. Elde edilen bulgulara göre, finansal başarısızlık ile finansal performans arasında pozitif ve anlamlı ilişki tespit edilmiştir. Çalışmanın kontrol değişkenleri konumunda olan aktif karlılık ve fiyat/kazanç oranı ile Tobin's Q arasında anlamlı ve pozitif yönlü ilişki belirlenirken, bir diğer kontrol değişkeni olan satışların logaritması ile Tobin's Q arasında istatistiksel olarak anlamlı bir ilişki tespit edilememiştir. Çalışmanın sonraki aşamasında ise çalışmanın metodolojisi açıklanmakta ve elde edilen bulgular değerlendirilmektedir. Son olarak ise çalışmanın sonuç ve değerlendirme bölümüne yer verilmektedir.

Çalışma, firmaların finansal başarısızlıklarını yalnızca tahmin yöntemleri ile belirlemek yerine, finansal performans ile finansal başarısızlık arasındaki ilişkiyi tespit etme, amaç açısından diğer mevcut çalışmalardan ayrışma ve yukarıda değinilen literatürdeki eksikliği ortadan kaldırma anlamında alan yazınına katkıda bulunmakta ve özgünlük sunmaktadır.

\section{METODOLOJİ}

$\mathrm{Bu}$ bölümde firmaların finansal başarısızlıkları ile finansal performansları arasındaki ilişkinin ortaya çıkarılması amacıyla gerçekleştirilen uygulamaya yönelik metodolojik bilgilere yer verilmektedir.

\subsection{Araştırmanın Amacı ve Kapsamı}

Araştırmada, firmaların finansal başarısızlıkları ile finansal performansları arasındaki ilişkiyi ortaya çıkarmak amaçlanmıştır. Bu doğrultuda, Borsa İstanbul 100 Endeksi (BIST 100) içerisinde imalat sanayinde faaliyet gösteren firmaların, 2011-2015 dönemindeki verileri analiz kapsamında incelenmiştir. Analiz verileri, Borsa İstanbul (www.borsaistanbul.com) ve Kamuyu Aydınlatma Platformu (www.kap.org.tr) internet sitelerinden elde edilmiştir.

BIST 100'de ilgili dönemde devamlı olarak faaliyet gösteren 19 firma analiz kapsamında incelenmiştir. Bu firmalar aşağıda Tablo 2'de gösterilmektedir. 
Tablo 2. 2011-2015 Dönemi BIST 100 İmalat Sanayi Şirketleri

\begin{tabular}{|c|c|c|}
\hline & BIST KODU & SİRKETLER \\
\hline 1. & AEFES & ANADOLU EFES BIRACILIK \\
\hline 2. & AFYON & AFYON CIMENTO \\
\hline 3. & ARCLK & ARCELIK \\
\hline 4. & AYGAZ & AYGAZ \\
\hline 5. & BAGFS & BAGFAS \\
\hline 6. & BFREN & BOSH FREN SISTEMLERI \\
\hline 7. & EREGL & EREGLI DEMIR CELIK \\
\hline 8. & FROTO & FORD OTOMOTIV SANAYI \\
\hline 9. & GOLTS & GOLTAS GOLLER BOLGESI CIMENTO SN \\
\hline 10. & GUBRF & GUBRE FABRIKALARI \\
\hline 11. & KARSN & KARSAN OTOMOTIV SAN TIC \\
\hline 12. & KARTN & KARTONSAN \\
\hline 13. & KRDMD & KARDEMIR D GRUBU \\
\hline 14. & OTKAR & OTOKAR OTOMOTIV VE SAVUNMA SANAI \\
\hline 15. & PETKM & PETKIM \\
\hline 16. & TOASO & TOFAS TURK OTOMOTIV FABRIKASI \\
\hline 17. & TRKCM & TRAKYA CAM \\
\hline 18. & TUPRS & TUPRS TURKIYE PETROL \\
\hline 19. & ULKER & ULKER BISKUVI SANAYI \\
\hline
\end{tabular}

Kaynak: www.borsaistanbul.com

\subsection{Araştırmanın Kısıtları}

Literatürde performans ölçütü olarak kullanılan aktif karlılığ1 ve öz sermaye karlılığı finansal başarı skoru hesaplamalarında kullanıldığından bağımlı değişken olarak kullanılamamıştır. Fulmer H-Skoru dışında modele dâhil edilen fiyat kazanç oranı, aktif karlılığı ve büyüklük değişkenleri Fulmer skoru hesaplamalarında yer almadığından ve Tobin's Q oranını etkileyeceği düşünüldüğünden kontrol değişkenleri olarak modele eklenmiştir. Çalışmanın örneklemini, 2011-2015 yılları arasında BIST 100 'de faaliyet gösteren imalat sanayi işletmelerinden oluşmaktadır. Makro düzeyde imalat sanayi sektöründe faaliyet gösteren firmaların ekonomide önemli bir yere sahip olması, mikro düzeyde ise finansal tablo verilerinin tutarlı olması ve elde edilen sonuçların daha genellenebilir olması gibi nedenler ile örneklem imalat sanayinde faaliyet gösteren firmalar ile sınırlandırılmıştır.

\subsection{Veri Seti ve Yöntem}

Çalışmada, BIST 100'de 2011-2015 yılları arasında imalat sanayinde devamlı olarak faaliyet gösteren ve finansal tablolarına eksiksiz ulaşılmış 19 işletmenin finansal başarı skoru hesaplanarak, finansal başarısızlığın finansal performans ile ilişkisi incelenmiştir. Çalışmanın, bağımlı değişkeni konumunda olan finansal performans, literatürde sıklıkla kullanılan Tobin's Q oranı ile ölçülürken, bağımsız değişken konumunda olan finansal başarısızlık ise Fulmer H-Skoru ile tespit edilmiştir. Çalışmada, finansal performansın Tobin's Q ile ölçülmesi, bu ölçütün piyasa bazlı 
performans göstergesi olması ve Fulmer H-Skora ilişkin hesaplamalar içerisinde etkisinin olmamasından kaynaklanmaktadır. Ayrıca çalışmada, finansal performansı etkilediği düşünülen fiyat kazanç oranı, aktif karlılığı ve firma büyüklüğü kontrol değişkenleri olarak analize dâhil edilmiştir. Analizlerde kullanılan değişkenler ve bu değişkenlere ilişkin hesaplama şekilleri ile notasyon bilgileri Tablo 3 'te gösterilmektedir.

Tablo 3. Araştırmada Kullanılan Bağımlı ve Bağımsız Değişkenler

\begin{tabular}{|c|c|c|c|}
\hline \multicolumn{2}{|c|}{ Değişken } & \multirow{2}{*}{$\begin{array}{c}\text { Notasyon } \\
\text { TQ }\end{array}$} & \multirow{2}{*}{$\begin{array}{l}\text { Hesaplama Yöntemi } \\
\text { (Toplam Varlıklar + Öz Sermaye Piyasa } \\
\text { Değeri - Öz Sermaye Defter Değeri) / } \\
\text { Toplam Varlıklar }\end{array}$} \\
\hline $\begin{array}{l}\text { Bağımlı } \\
\text { Değişken }\end{array}$ & $\begin{array}{l}\text { Tobin's Q } \\
\text { Oranı }\end{array}$ & & \\
\hline $\begin{array}{l}\text { Bağımsız } \\
\text { Değişken }\end{array}$ & $\begin{array}{l}\text { Fulmer } \\
\text { H-Skoru }\end{array}$ & HS & $\begin{array}{l}\text { X1) Dağıtılmamış Kar/T. Varlık } \\
\text { (X2) Satış/T. Varlık } \\
\text { (X3) Vergi Öncesi Kar/Özsermaye } \\
\text { (X4) Nakit/Toplam Borç } \\
\text { (X5) Toplam Borç/T. Varlık } \\
\text { (X6) Kısa Vadeli Borç/T. Varlık } \\
\text { (X7) Log(Maddi Duran Varlık) } \\
\text { (X8) Çalışma Sermayesi/Toplam Borç } \\
\text { (X9) Log Faiz ve Vergi Öncesi K./Faiz } \\
\text { H: 5,52X1+0,212X2+0,073X3+1,27X4- } \\
\text { 0,12X5+2,34X6+0,575X7+1,083X8+0,8 } \\
94 \text { X9-6,075 }\end{array}$ \\
\hline \multirow{3}{*}{$\begin{array}{c}\text { Kontrol } \\
\text { Değişkenleri }\end{array}$} & $\begin{array}{c}\text { Aktif } \\
\text { Karlılık }\end{array}$ & ROA & Net Kar / Toplam Varlıklar \\
\hline & $\begin{array}{c}\text { Fiyat Kazanç } \\
\text { Oranı }\end{array}$ & $\mathrm{F} / \mathrm{K}$ & $\begin{array}{l}\text { Toplam Piyasa Değeri / Son iki 6'şar } \\
\text { Aylık Bağımsız Denetimden Geçmiş } \\
\text { Dönemin Net Karlar-Zararlar Toplamı }\end{array}$ \\
\hline & $\begin{array}{l}\text { Büyüklük } \\
\text { Değişkeni }\end{array}$ & $\operatorname{Ln}(\mathrm{S})$ & Toplam Satışların Doğal Logaritması \\
\hline
\end{tabular}

Araştırmada, 2011 ile 2015 y1lları arasında BIST 100'de imalat sanayinde devamlı olarak faaliyet gösteren 19 firmanın başarısızlık skorları ile finansal performansları arasındaki ilişki, panel veri analiz yöntemi kullanılarak incelenmiştir.

\subsection{Araştırmanın Hipotezleri ve Modeli}

Araştırmanın teorik alt yapısı doğrultusunda test edilecek hipotezler ve bu hipotezleri test edebilmek için panel regresyon analizi doğrultusunda oluşturulan modele ilişkin bilgiler aşağıda Tablo 4'te yer almaktadır. 
Tablo 4. Hipotezler ve İlişki Yönü

\begin{tabular}{lc} 
Hipotezler & $\begin{array}{c}\text { Beklenen } \\
\text { Ilişkinin Yönü }\end{array}$ \\
Hipotez 1: Fulmer H-Skoru ile Tobin's Q arasında bir ilişki vardır. & + \\
Hipotez 2: Aktif Karlılık Oranı ile Tobin's Q arasında bir ilişki vardır. & + \\
Hipotez 3: Fiyat/Kazanç Oranı ile Tobin's Q arasında bir ilişki vardır. & + \\
Hipotez 4: Firma Büyüklüğü ile Tobin's Q arasında bir ilişki vardır. & + \\
\hline
\end{tabular}

Araştırma hipotezlerini sınayabilmek için panel regresyon analizi doğrultusunda oluşturulan model aşağıdaki gibi kurgulanmıştır.

$$
\text { Yit }=\alpha 0 \text { it }+\beta 1 \text { itHSit }+\beta 1 \text { itROAit }+\beta 4 \text { it } \operatorname{Ln}(\mathrm{S}) \text { it }+\beta 5 \text { itF } / \text { Kit }+ \text { Eit }
$$

\subsection{Bulgular}

Firmaların finansal başarı skoru ile finansal performansa arasındaki ilişki panel regresyon yöntemi ile incelenmiştir. Analizler Eviews 8 ve Stata 11 paket programları kullanılarak gerçekleştirilmiştir. Panel veri regresyon yöntemi kapsamında elde edilen tahmin sonuçlarına geçilmeden önce değişkenlere ilişkin birim kök testi sonuçları ve tanımlayıcı istatistiklere ilişkin bulgulara yer verilmiştir.

Panel veri regresyon modellerinde değişkenler arasındaki ilişkinin ortaya çıkarılabilmesi için analiz edilen zaman serilerinin durağan olmaları gerekmektedir (Gujarati, 2003). Bu bağlamda serilerin durağanlık analizleri, birinci nesil birim kök testlerinden biri olan PP-Fisher birim kök testleri ile gerçekleştirilmiştir. Çalışmanın kapsamı doğrultusunda incelenen gözlem sayısının az oluşu nedeniyle, zaman serilerin durağanlığ 1 sadece PP-Fisher birim kök testi analiz edilmiştir. Birim kök testlerine ait sonuçlar Tablo 5'te gösterilmektedir.

Tablo 5. Phillips-Perron Birim Kök Testi Sonuçları

\begin{tabular}{|c|c|c|}
\hline Değişkenler & Sabitli & Sabitli/ Trendli \\
\hline TQ & $72,2527 * * *$ & $116,248 * * *$ \\
\hline HS & $52,6767^{*}$ & $55,3565^{* *}$ \\
\hline ROA & $59,1512 * *$ & $78,9050 * * *$ \\
\hline F/K & $57,2563^{* *}$ & $65,8722 * * *$ \\
\hline $\operatorname{Ln}(\mathbf{S})$ & $73,7339 * * *$ & $69,9283 * * *$ \\
\hline \multirow{2}{*}{\multicolumn{3}{|c|}{$\begin{array}{l}\text { Not 1: Tabloda; Tobin's Q (TQ), Fulmer H-Skoru (HS), Akt } \\
\text { Karlılık Oranı (ROA), Fiyat Kazanç Oranı (F/K) ve Firm } \\
\text { Büyüklügüu }(\mathbf{L n}(\mathbf{S})) \text { ile gösterilmektedir. }\end{array}$}} \\
\hline Not $2: * * * \% 1$, & & \\
\hline
\end{tabular}

Birim kök analizi sonucunda değişkenlere ilişkin olasılık değerlerinin $\% 1$ ve $\% 5$ kritik değerlerinden küçük olduğu ve serilerin sabitli ve sabitli/trendli modelde durağan olduğu tespit edilmiştir. Dolayısıyla finansal başarısızlık ile finansal performans 
arasındaki ilişkiyi test edebilmek için kullanılan zaman serilerinin analiz için uygun olduğu tespit edilmiştir.

Birim kök analiz sonuçlarından sonra, çalışmada kullanılan değişkenlere ilişkin tanımlayıcı istatistik bulguları aşağıda Tablo 6'da gösterilmektedir.

Tablo 6. Tanımlayıcı İstatistik Sonuçları

\begin{tabular}{ccccccc}
\hline Değişken & Ortalama & Medyan & S. Sapma & Maksimum & Minimum & Jarque-Bera \\
\hline TQ & 1,8058 & 1,3481 & 11,2948 & 7,2241 & 0,7300 & $241,12^{* * *}$ \\
HS & 17,6719 & 17,886 & 11,5925 & 23,241 & 14,120 & $9,9439^{* * *}$ \\
ROA & 0,0714 & 0,0675 & 00,0754 & 0,4356 & $-0,1519$ & $1,3026^{* * *}$ \\
F/K & 17,672 & 11,519 & 19,9156 & 109,927 & 0,0000 & $2,3450^{* * *}$ \\
Ln(S) & 0,0525 & 0,0401 & 00,0980 & 0,4569 & $-0,4060$ & $1,7806^{* * *}$ \\
\hline
\end{tabular}

Not 1: Tabloda; Tobin's Q (TQ), Fulmer H-Skoru (HS), Aktif Karlı1ı Oranı (ROA), Fiyat Kazanç Oranı (F/K) ve Firma Büyüklüğü $(\mathbf{L n}(\mathbf{S}))$ ile gösterilmektedir.

Not 2: $* * * \% 1, * * \% 5, * \% 10$ anlamll1lk düzeyini ifade etmektedir.

Fulmer H-Skoru 0'ın altında olan firmaların başarısız olduğu kabul edilmektedir. Tablo 6 incelendiğinde örneklem kapsamındaki firmaların ortalama Fulmer $\mathrm{H}$ Skoru'nun 17,67 olduğu ve kritik değerin oldukça üstünde olduğu anlaşılmaktadır. Dolayısıyla çalışmada incelenen firmaların, finansal sıkıntı ve iflas maliyetlerinin düşük olduğu ve finansal olarak başarılı oldukları belirlenmiştir. Örneklem kapsamındaki firmaların ortalama TQ değeri ise 1,8'dir. TQ değerinin 1'den büyük olması, örnekleme dâhil edilen firmalarda eldeki kaynakların verimli kullanıldığını ve büyüme fırsatlarının yüksek düzeyde olduğunu söylemek mümkündür (Canbaş, Doğukanlı ve Düzakın, 2004: 58). Kontrol değişkenlerinden ROA'nın ortalama değeri 0,07 iken, fiyat kazanç oranı 17,67, satışların ortalama büyüklüğü ise 0,05 olarak tespit edilmiştir. Tanımlayıcı istatistikler standart sapma açısından değerlendirildiğinde ise yıllar itibariyle fiyat kazanç oranı dışında tüm değişkenlerde önemli ölçüde değişkenlik yaşanmadığını söylemek mümkündür. Jarque-Bera olasılık değerleri incelendiğinde ise serilere ait hata terimlerinin normal dağılıma uyduğu anlaşılmaktadır.

Firmaların finansal başarısızlıkları ile finansal performansları arasındaki ilişki panel veri yöntemi ile incelenmiştir. Bu kapsamda model tahmininde havuzlanmış en küçük kareler yöntemi, sabit etkiler ve rassal etkiler yönteminin hangisinin tercih edileceği F testi, Breusch-Pagan Lagrange Çarpanı ve Hausman testi ile incelenmiştir. $\mathrm{Bu}$ bağlamda sabit etkiler modeline karşın havuzlanmış en küçük kareler yönteminin kullanılıp kullanılamayacağı, F testi ile sınanmıştır. Analiz sonucunda F istatistik değerinin $\mathrm{F}$ tablo değerinden daha büyük olduğu $(\mathrm{p}<0,05)$ belirlenmiş ve birim etkilerin sıfıra eşit olduğu H0 hipotezi reddedilmiştir. Tesadüfi etkiler modeline karşı havuzlanmış en küçük kareler yönteminin uygunluğunu sınamak için ise Breusch-Pagan 
Lagrange Çarpanı testi kullanılmıştır. LM test istatistiği (chi2(1)) ve olasılık değeri 1 serbestlik dereceli ki kare istatistik tablosu ile karşılaştırıldığında birim etkilerin varyansının sıfıra eşit olduğu H0 hipotezi reddedilmiştir. F testi ve Breusch-Pagan Lagrange Çarpanı testi sonuçları Tablo 7'de gösterilmektedir.

Tablo 7. Breusch-Pagan Lagrange Çarpanı ve F Testi

\begin{tabular}{clll}
\hline \multirow{3}{*}{ Breusch-Pagan Lagrange Çarpanı } & Hipotez & $\mathrm{H}_{0}: \operatorname{Var}(\mathrm{u})=0$ & \\
& Ki Kare İstatistiği & chi2(1) & 98,25 \\
& Olasılık Değeri & Prob > chi2 & 0,0000 \\
\hline \multirow{2}{*}{ F Testi } & Hipotez & $\mathrm{H}_{0}: \mu_{1}=\mu_{2}=\ldots \mu_{\mathrm{n}-1}=0$ & \\
& F İstatistiği & $\mathrm{F}(18,72)$ & 20,93 \\
& Olasılık Değeri & Prob > chi2 & 0,0000 \\
\hline
\end{tabular}

F testi ve Breusch-Pagan Lagrange Çarpanı testi sonuçlarına göre modelin havuzlanmış en küçük kareler yöntemi ile tahmin edilmeye uygun olmadığı ve modelde birim etkilerin var olduğu anlaşılmaktadır. Bu doğrultuda model tahmininde sabit etkiler tahmincisi ve rassal etkiler tahmincisinden hangisinin kullanılacağ 1 Hausman (1978) testi ile karar verilmiş̧tir. Hausman testi sonuçları Tablo 8'de gösterilmektedir.

Tablo 8. Hausman Testi Sonuçları

\begin{tabular}{ll|l}
\hline & Hipotez & $\mathrm{H}_{0}:$ Rassal etkiler mevcuttur \\
Hausman Testi & Ki Kare İstatistiği & 12,94 \\
& Olasılık Değeri & 0,0116 \\
\hline
\end{tabular}

Hausman test istatistiği olasıllı değeri 0,05 ' in altında olduğundan modelin rassal etkiler tahmincisi ile tahmin edilmeye uygun olmadığı anlaşılmaktadır. Sonuç olarak model tahmininde havuzlanmış en küçük kareler yöntemi ve rassal etkiler tahmincisinin uygun olmadığ 1 ve modelin sabit etkiler tahmincisi ile tahmin edilmesi gerektiği gözlemlenmiştir.

Tahmin edilen modelin etkinliğini ve tutarlılı̆̆ını etkileyen değiş̧en varyans ve otokorelasyon olup olmadığı sabit etkiler tahmincisi ile tahmin edilen modellerde değiştirilmiş wald testi ile test edilirken, otokorelasyon problemi ise Baltagi Wu LBI yerel en iyi değişmez testi ve Durbin Watson testi ile sınanabilmektedir (Yerdelen Tatoğlu, 2013: 208). Sabit etkiler tahminci ile tahmin edilen modelde değişen varyans değiştirilmiş wald testi ile sınanırken, otokorelasyon ise Baltagi Wu LBI ve Durbin Watson testi ile sinanmıştır. Elde edilen sonuçlar Tablo 9'da gösterilmektedir. 
Tablo 9. Değişen Varyans ve Otokorelasyon Testi Sonuçları

\begin{tabular}{lll}
\hline \multirow{2}{*}{ Değiştirilmiş Wald Testi } & Hipotez & $\mathrm{H}_{0}: \sigma^{2}{ }_{\mathrm{i}}=\sigma^{2}$ \\
& Test İstatistiği & 43108,94 \\
& Olasılık Değeri & 0,0000 \\
\hline \multirow{2}{*}{ Baltagi Wu LBI } & Hipotez & $\mathrm{H}_{0}: \mathrm{p}=0$ \\
& Test Istatistiği & 2,84 \\
\hline \multirow{2}{*}{ Durbin-Watson } & Hipotez & $\mathrm{H}_{0}: \mathrm{p}=0$ \\
& Test Istatistiği & 2,92 \\
\hline
\end{tabular}

Tablo 9 incelendiğinde, değiştirilmiş wald testi sonucu elde edilen olasılık değeri istatistiki olarak anlamlıdır ve tüm yatay kesit birimlerine ait hata terimlerinin eşvaryansa sahip olduğuna dayanan $\mathrm{H} 0$ hipotezi reddedilmektedir. Literatürde kritik değerler verilmemesine rağmen, Baltagi-Wu LBI ve Durbin-Watson istatistik değeri 2 'den küçük ise otokorelasyonun önemli olduğu yorumu yapılabilmektedir (Yerdelen Tatoğlu, 2013: 214). Tablodan da görüleceği üzere Baltagi-Wu LBI değeri 2'den büyük, Durbin Watson değeri ise 2,92 olarak hesaplanmıştır. Elde edilen d değeri ise $(2,92)$ \%95 güven düzeyinde Durbin Watson d istatistiği çizelgesi ile karşılaştırıldığında, Durbin watson istatistiğinin kararsız bölgede yer aldığı anlaşılmaktadır. Dolayısıyla modelde değişen varyans probleminin olduğu ancak otokorelasyon sorunun önemli olmadığı anlaşılmaktadır. Değişen varyans probleminin olduğu anlaşılan model, White Cross section ağırlıklandırılması yapılarak tahmin edilmiştir. Elde edilen sonuçlar Tablo 10 'da gösterilmektedir.

Tablo 10. Finansal Başarısızlık ile Finansal Performans Arasındaki İlişkiye ait Analiz Sonuçları

\begin{tabular}{rrrrr}
\hline Değişkenler & Korelasyon Katsayısı & Standart Hata & t- istatistiği & P Değeri \\
\hline $\mathrm{C}$ & 1.4710 & 0.1114 & 13.202 & $0.0000^{* * *}$ \\
$\mathrm{HS}$ & 0.0113 & 0.0056 & 1.9964 & $0.0497 * *$ \\
$\mathrm{ROA}$ & 1.3625 & 0.3987 & 3.4173 & $0.0010^{* * *}$ \\
$\mathrm{~F} / \mathrm{K}$ & 0.0028 & 0.0011 & 2.4148 & $0.0183^{* *}$ \\
LN(S) & -0.2434 & 0.1579 & -1.5408 & 0.1277 \\
R-Kare & 0.9166 & & & \\
Düzeltilmiş R-Kare & 0.8911 & & & \\
F-İstatistiği & 35.977 & & & \\
Prob (F-İstatistiği) & $0.0000 * * *$ & & & \\
\hline
\end{tabular}

Bağımlı Değişken: TQ, Yöntem: Panel EGLS (Cross-section weights)

Örneklem Periyodu: 2011-2015, Yatay Kesit Sayısı: 19, Toplam Gözlem Sayısı: 95

Not 1: Tabloda; Tobin's Q (TQ), Fulmer H-Skoru (HS), Aktif Karlılık Oranı (ROA), Fiyat Kazanç Oranı (F/K) ve Firma Büyüklüğü $(\mathbf{L n}(\mathbf{S}))$ ile gösterilmektedir.

Not 2: $* * * \% 1, * * \% 5, * \% 10$ anlamlllık düzeyini ifade etmektedir. 
Modelin anlamlı olup olmadığını ifade eden $\mathrm{F}$ istatistik değerine göre modelin \%99 güven aralığında anlamlı olduğu belirlenmiştir. Analizde, Fulmer H-Skor bağımsız değişkeni ve kontrol değişkenleri, bağımlı değişken konumunda olan Tobin's Q oranında meydana gelen değişimlerin yaklaşık \%89'unu açıklamaktadır. Analiz sonuçlarına göre finansal başarısızlık göstergesi olan Fulmer H-Skoru ve kontrol değişkenleri konumunda olan ROA ve F/K oranı ile Tobin's Q oranı arasında pozitif ve anlamlı bir ilişki tespit edilirken, bir diğer kontrol değişkeni olan firma büyüklüğü ile anlamlı bir iliş̧ki tespit edilememiştir. Dolayısıyla çalışma kapsamında oluşturulan hipotez 1, 2 ve 3 kabul edilirken, hipotez 4 reddedilmektedir.

\section{SONUÇ ve DEĞERLENDİRMELER}

Çalışmada, 2011-2015 yılları arasında BIST 100 endeksi içerisinde devamlı olarak faaliyet gösteren 19 imalat sanayi firmasının, finansal başarısızlıkları ile finansal performansları arasındaki ilişki incelenmiş̧ir. Analizde finansal başarısızlık Fulmer HSkoru ile temsil edilirken, finansal performans ise Tobin's Q ile temsil edilmiştir. Ayrıca finansal performansı etkilediği düşünülen aktif karlılık oranı, satışların logaritması ve fiyat/kazanç oranı analize kontrol değişkenleri olarak dâhil edilmiştir. Finansal başarısızlık ile finansal performans arasındaki ilişkiyi tespit edebilmek için panel veri analiz yöntemi kullanılmıştır. Panel veri analizi kapsamında zaman serilerinin durağan olup olmadığı, PP-Fisher birim kök testi ile sınanmıştır. Model tahmininde havuzlanmış en küçük kareler yöntemi, sabit etkiler ve rassal etkiler yönteminin hangisinin tercih edileceği ise $\mathrm{F}$ testi ve Breusch-Pagan Lagrange Çarpanı ile karar verilmiştir. Yapılan analizler neticesinde finansal başarısızlık ile finansal performans arasındaki ilişki, sabit etkiler modeli ile tahmin edilmiştir.

Analiz sonuçlarına göre, Fulmer H-Skoru ile Tobin's Q oranı arasında pozitif ve anlamlı bir ilişki tespit edilmiş̧tir. Diğer bir ifadeyle, H-Skor'da meydana gelen bir birim değişim, Tobin's Q'da 0,011 birimlik artı̧a yol açmaktadır. Dolayısıyla Fulmer H-Skorun artması, firmaların finansal olarak başarısını artırmaktadır. Finansal başarısı skoru artan firmalara yatırımcıların daha fazla talep göstermesi ve yatırım yapması, firmanın piyasa değerini yükseltmektedir. Ayrıca bu firmaların kaynaklarını oldukça verimli kullandıkları ve bu etkinliğin finansal performansa olumlu yönde etki ettiği söylenebilir. Bu durum da finansal başarısızlık ile Tobin's Q oranı arasındaki ilişkiye yönelik çalışmada elde edilen bulguları açıklamaktadır. Bu bulgu, Shahwan (2015), Shaukat ve Affandi (2015) ve Delavar, Kangarluei ve Motavassel (2015) tarafindan yapılan çalışmalarda elde edilen bulgular ile farklı yönde sonuçlar göstermektedir. $\mathrm{Bu}$ doğrultuda çalışma kapsamında oluşturulan Hipotez 1 kabul edilmektedir. Çalışmanın kontrol değişkeni konumunda olan ROA ile Tobin's $Q$ arasında anlamlı ve pozitif yönlü 
ilişki belirlenmiştir. Bu bağlamda ROA'da gerçekleşen bir birim değişim, Tobin's Q'da 1,3625 birimlik artışa yol açmaktadır. Bir diğer kontrol değişkeni F/K oranı ile Tobin’s $\mathrm{Q}$ arasında pozitif ve anlamlı bir ilişki tespit edilmiştir. Bu bulguya göre $\mathrm{F} / \mathrm{K}$ oranında bir birim değişim, Tobin's Q'da 0,0028 birimlik artışa neden olmaktadır. Diğer taraftan çalışmanın son kontrol değişkeni konumunda olan Lnsatış ile Tobin's Q arasında istatistiksel olarak anlamlı bir ilişki tespit edilememiştir. Dolayısıyla hipotez 2 ve 3 kabul edilirken, hipotez 4 kabul edilmemektedir.

\section{4. ÖNERILER}

Bu çalışma, analiz döneminin yıl itibariyle genişletilmesi, çeşitli ülkelerin benzer nitelikte piyasaları ile mukayese edilmesi, diğer başarısızlık tahmin modellerinin kullanılması ve farklı analiz yöntemlerinin uygulanması ile sonraki çalışmalarca geliştirilebilir.

\section{KAYNAKLAR}

Aktaş, Ramazan - Doğanay, Mete - Yıldız, Birol (2003), "Mali Başarısızlığın Öngörülmesi: İstatistiksel Yöntemler ve Yapay Sinir Ağı Karşılaştırması”, Ankara Üniversitesi SBF Dergisi, Cilt.58, Say1 4, ss. 1-24.

Borsa İstanbul (2016), www.borsaistanbul.com.

Campbell, John - Hilscher, Jens Dietrich - Szilagyi, Jan (2011), "Predicting Financial Distress and The Performance of Distressed Stocks", Journal of Investment Management, Cilt. 9, Sayı. 2, ss. 14-34.

Canbaş, Serpil - Doğukanlı, Hatice - Düzakın, Hatice (2004), "Tobin Q Oranı ve Günümüzde İşletme Kararları Açısından Önemi”, Çukurova Üniversitesi Sosyal Bilimler Enstitüsü Dergisi, Cilt.13, Sayı. 2, ss. 57-74.

Delavar, Alireza - Kangarluei, Saeid Jabbarzadeh - Motavassel, Morteza (2015), "Working Capital, Firms Performance and Financial Distress in Firms Listed in Tehran Stock Exchange (TSE)", Indian Journal of Fundamental and Applied Life Sciences, Cilt. 5, Say1. 1, pp. 2086-2093.

Fulmer, John - Moon, James - Gavin, Thomas - Erwin, Michael (1984), “A Bankruptcy Classification Model For Small Firms", Journal of Commercial Bank Lending, Cilt. 66, Sayı. 11, pp. 25-37.

Gujarati, Damadoran (2003), Basic Econometrics. McGraw Hill Book Co, New York.

Hausman, Jerry (1978), "Specification Test in Econometrics", Econometrica, Cilt. 46, Say1. 6, pp. 1251-1271.

Kamuyu Aydınlatma Platformu (2016), www.kap.org.tr. 
Selimoğlu, Seval - Orhan, Abdullah (2015), "Finansal Başarısızlığın Oran Analizi ve Diskriminant Analizi Kullanılarak Ölçümlenmesi: BİST'de İşlem Gören Dokuma, Giyim Eşyası ve Deri İşletmeleri Üzerine Bir Araştırma”, Muhasebe ve Finansman Dergisi, Cilt. 17, Sayı. 66, ss. 21-40.

Shahwan, Tamer Mohamed (2015), "The effects of Corporate Governance on Financial Performance and Financial Distress: Evidence from Egypt", Corporate Governance, Cilt. 15, Sayı. 5, pp. 641-662.

Shaukat, Arzish - Affandi, Hina (2015), "Impact of Financial Distress on Financial Performance to Pakistani Corporate Sector", International Journal of Current Research, Cilt. 7, Sayı. 2, pp. 12991-12996.

Tan, Tih Koon (2012), "Financial Distress and Firm Performance: Evidence From The Asian Financial Crisis", Journal of Finance \& Accountancy, Cilt. 11, Sayı. 36.

Opler, Tim - Titman, Sheridan (1994), "Financial Distress and Corporate Performance", The Journal of Finance, Cilt. 49, Say1. 3, pp. 1015-1040.

Yerdelen Tatoğlu, Ferda (2013), Panel Veri Ekonometrisi, Beta Yayınları, İstanbul.

Yusuf, Mazila - Karim, Yaasmin Farzana - Yunus, Fauziah Mohamed (2014), "Financial Distress and Performance Relationship of Banks in Malaysia", 5th International Conference On Business And Economic Research Proceeding, Kuching,Sarawak, Malaysia. 